\title{
Unusual foreign body in primary tooth
}

\author{
Pratej Kiran Kanumuri, ${ }^{1}$ Sribala Naga Gantha, ${ }^{2}$ Dwitha Animireddy, ${ }_{1}{ }^{\text {Mahesh }}$ Chinta $^{2}$
}

${ }^{1}$ Panineeya Institute of Dental Sciences and Hospital, Hyderabad, Telangana, India ${ }^{2}$ Department of pedodontics and preventive dentistry, Panineeya Mahavidyalaya Institute of Dental Sciences and Research Centre, Hyderabad, Telangana, India

\section{Correspondence to} Dr Pratej Kiran Kanumuri, pratejkiran@gmail.com

Accepted 22 June 2016

\section{DESCRIPTION}

Foreign bodies inside teeth are diagnosed accidentally on clinical or radiographic examination of teeth. These may be associated with infection, pain, swelling, and recurrent abscesses as a sequel to the pulpal exposure and lodgement of the foreign body. ${ }^{1}$ Various foreign bodies reported were pencil leads, metal screws, stapler pins and tooth-picks. ${ }^{2}$ The exogenous material acts as a focus for infection and may cause tissue irritation. ${ }^{3}$ There are various radiographic methods, such as Parallax views, Triangulation techniques, Stereo Radiography, Tomography, Radiovisiography and CT scans, that can play a pivotal role in focusing on the localisation of foreign objects inside the root canal. ${ }^{4}$ The dentist plays a vital role in diagnosis of such

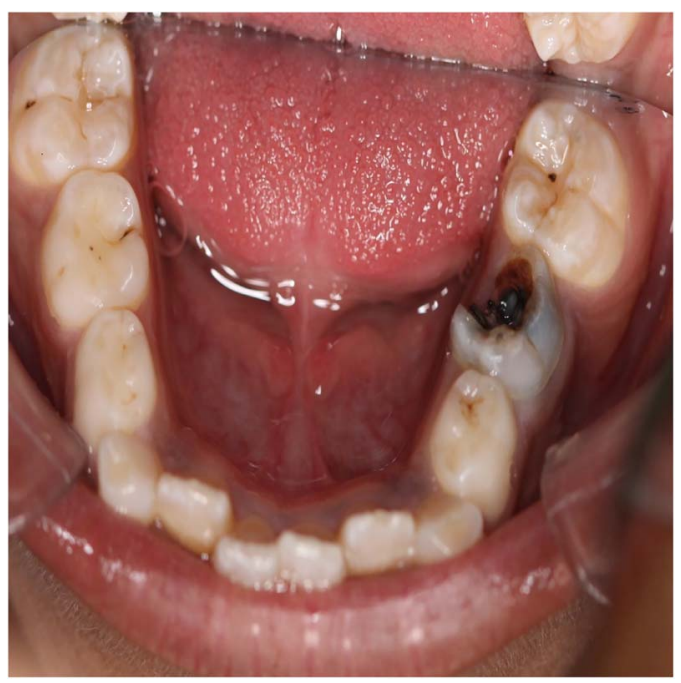

Figure 1 Grossly decayed irt75.

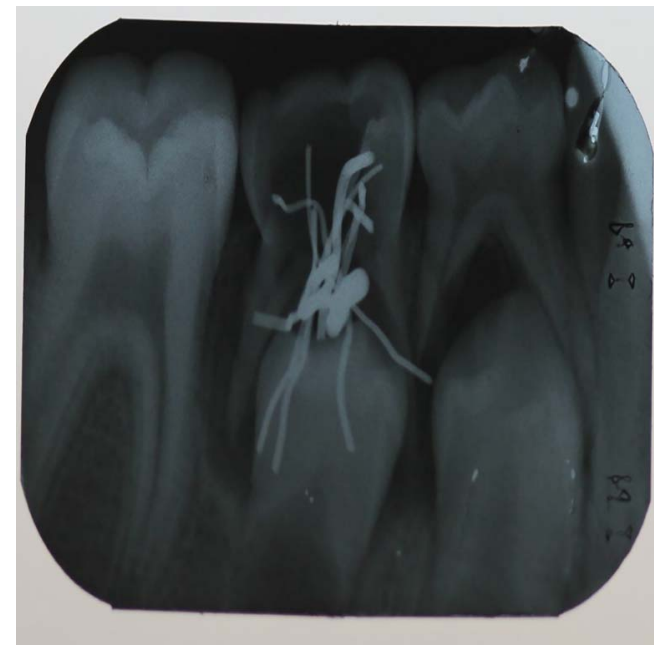

Figure 2 Preoperative radiograph irt 75. embedded foreign bodies. The case presented here is of a similar entity, but with an unusual embedded foreign body.

A 10-year-old male patient presented to the department with pain in the lower left back tooth region for the past 1 week. Pain was intermittent, moderate, throbbing in nature and non-radiating, with no history of abscess. Clinical examination revealed a grossly decayed primary mandibular left second molar (75 ISO system) (figure 1). Intraoral periapical radiograph had been taken in relation to that region, and many multiple radiopaque lines were observed extending from pulp chamber on to its successor (35 ISO system) in the furcation area (figure 2). It was assumed to be an artefact, as there was no visible foreign body. The radiograph was then repeated to confirm the diagnosis and similar findings were observed. Extraction of 75 was carried under local anaesthesia, along with administration of a tetanus vaccine booster. Seven metal wires and one staple pin were retrieved along with the extracted tooth (figure 3). When questioned about the existence of the foreign body, the patient admitted placing several metal wires from a sand sieving mesh and also a stapler pin into the tooth to relieve pain. Systemic antibiotics and analgesics

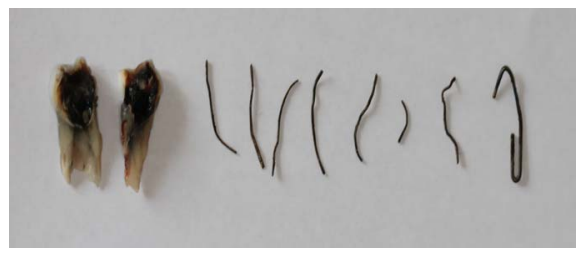

Figure 3 Foreign body recovered from extracted wound.

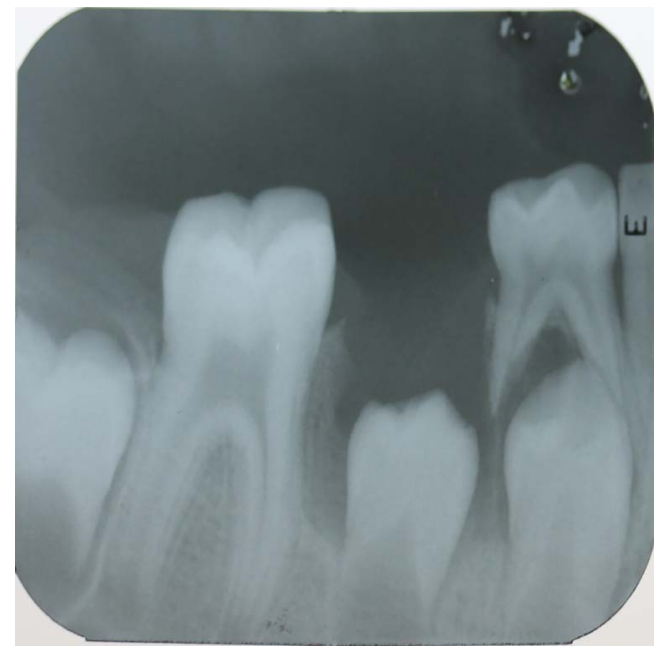

Figure 4 Postoperative radiograph irt 75. 
(amoxicillin $250 \mathrm{mg}, 8$ hourly for 5 days and acetaminophen $250 \mathrm{mg}, 8$ hourly for 5 days) were administered following the tooth extraction (figure 4). Foreign bodies are commonly seen in large untreated open carious lesions as a self-inflicting injury to relieve pain. Majority of cases of accidental ingestion or aspiration of foreign objects in children occur between the ages of 6 months and 3 years. ${ }^{5}$ In these cases, timely diagnosis can

\section{Learning points}

- Main reasons for insertion of foreign objects into these teeth are food impaction and pain. This then becomes a habit over a period of time if left untreated.

- Proper counselling should be carried out to ensure that dental treatment is provided at the earliest to prevent such untoward incidents. prevent complications such as ingestion and damage to the successor teeth. Proper counselling should be carried out to ensure that dental treatment is provided at the earliest to prevent such untoward incidents.

Contributors PKK handled the patient. SNG contributed by preparing the manuscript. DA took the photographs. MC assisted chair side.

Competing interests None declared.

Patient consent Obtained.

Provenance and peer review Not commissioned; externally peer reviewed.

\section{REFERENCES}

1 Nerst H. Foreign body in the root canal. Quintessence Int (Berl) 1972:3:33-4.

2 Aduri R, Reddy RE, Kiran K. Foreign objects in teeth: retrieval and management. I Indian Soc Pedod Prevent Dent 2009;27:179-83.

3 Nair PNR. On the causes of persistent apical periodontitis: a review. Int Endod J 2006;39:249-81.

4 McAuliffe N, Drage NA, Hunter B. Staple diet: a foreign body in a tooth. Int J Paediatr Dent 2005;15:468-71.

5 Van $A s A B$, du Toit $N$, Wallis $L$, et al. The South African experience with ingestion injury in children. Int J Pediatr Otorhinolaryngol 2003;67:S175-8.

Copyright 2016 BMJ Publishing Group. All rights reserved. For permission to reuse any of this content visit

http://group.bmj.com/group/rights-licensing/permissions.

BMJ Case Report Fellows may re-use this article for personal use and teaching without any further permission.

Become a Fellow of BMJ Case Reports today and you can:

- Submit as many cases as you like

- Enjoy fast sympathetic peer review and rapid publication of accepted articles

- Access all the published articles

- Re-use any of the published material for personal use and teaching without further permission

For information on Institutional Fellowships contact consortiasales@bmjgroup.com

Visit casereports.bmj.com for more articles like this and to become a Fellow 